\title{
Audit Quality in Government Audit: Public Accountant Firm vs. Government Auditors in Indonesia
}

\author{
Imam Ulil Amri, Dyah Setyaningrum* \\ Department of Accounting, Universitas Indonesia, Depok, Indonesia \\ *Corresponding author.Email: dsetyani@ui.ac.id
}

\begin{abstract}
This study aims to investigate the difference in audit quality between the Public Accounting Firms (PAF) in Indonesia and the Audit Board of the Republic of Indonesia (BPK). We conducted a test using two sample groups of local governments from 2016 until 2018. The first group consists of local governments audited by PAF compared to the other local governments audited by BPK using paired match sample criteria. The second group consists of local governments audited by PAF compared to the same local governments audited by BPK in the previous year. We apply quantitative research using a regression test and t-test of two sample groups. The result shows that the use of PAF auditors did not affect the number of audit findings compared with BPK auditors. The additional analysis shows that there is no significant difference in the number of findings between PAF auditors and BPK auditors between 2017 through 2018. The result implies that the BPK should continue to use PAF auditors in the government financial audit process.
\end{abstract}

Keywords: Audit Findings, Audit Quality, Government Auditors, Public Accounting Firm, Badan Pemeriksa Keuangan

\section{INTRODUCTION}

The market of public sector audit is monopolistic (Clark et al., 2007). Public sector audit becomes monopolistic because the Supreme Audit Institution (SAI) controls all audit activities (Clark et al., 2007). The monopolistic nature of the public sector audit eliminates competition. The organization that monopolizes the market has the power to control the matter. The control of public sector audit can reduce competition, which can produces a greater audit quality (Ciconte et al., 2015). Giroux and Jones (2011) state that PAF auditors' involvement in the public sector audit can create an atmosphere of competition with government auditors that aim to improve the quality of the overall public sector audit. Therefore, SAI has been involving PAF auditors for many years in developed countries.

In the Indonesian context, act No. 15 of 2004 stated that BPK RI has been mandated to conduct the government financial audit. BPK RI is the only organization that has the authority in auditing government financial reports (Setyaningrum et al.,
2013). Government auditors in BPK RI were the only ones that have performed audit services for all government financial reports from 2004 to 2015. BPK RI started to appoint Public Accounting Firms (PAF) to perform government financial audit since 2016. The 2017 Annual Report of BPK RI stated that one of the reasons to involve PAF in the government financial audit is the lack of resources of BPK RI. Government auditors comply with the Government Financial Auditing Standards (SPKN), which are different from the Public Accountants Professional Standards (SPAP). PAF auditors should make adjustments in order to maintain the quality of audit services at the desired level. Therefore, BPK RI requires PAF auditors to be certified. The certification requirement aims to ensure the competency and capability of PAF auditors. It also helps PAF auditors to speed their adjustment process.

In general, there were differences in the level of audit quality between the government auditors and the PAF auditors (Giroux \& Jones, 2011). Previous studies found that the type of auditor significantly affected the audit quality (Cagle \& Pridgen, 2015; Giroux \& Jones, 2011; Jeffrey, 2011; López \& Peters, 2010). However, those studies have not been conclusive on the magnitude 
of the impact on the audit quality. Nonetheless, previous studies such as Giroux and Jones (2011) and López and Peters (2010) showed that the PAF classified as the Big4 have a positive effect on audit quality. Those results indicate that PAF auditors provide better audit quality compared to government auditors (Giroux \& Jones, 2011). PAFs that are not classified as the Big4 do not have a significant effect on audit quality in the public sector audit (Giroux \& Jones, 2011). Other studies such as Cagle and Pridgen (2015) and Jeffrey (2011) found that PAF auditors had a negative effect on audit quality. These findings indicated that government auditors produce better audit quality than PAF auditors in some circumstances (Cagle \& Pridgen, 2015; Jeffrey, 2011). Government auditors could produce better audit quality because they had more experience as well as a greater risk of penalties (Cagle \& Pridgen, 2015).

BPK RI began to use the services of the PAF to conduct government financial audits in 2012. The BPK RI only gave three government financial reports to be audited by PAF in 2012. However, BPK RI started to appoint PAF auditors to conduct a local government financial audit in 2016. BPK RI used the services of PAF auditors to conduct a financial audit for 25 local governments in 2016. However, the BPK RI only used the services of PAF auditors to conduct a financial audit for 12 local governments in 2017. The number of local governments increased to 35 in 2018.

The study uses a number of audit findings on measuring government financial audit quality. Government financial audit provides attributes that allow measuring audit quality by using a number of audit findings (Cagle \& Pridgen, 2015). Audit findings are all the material weaknesses that were found by the auditor during the audit process. The study uses a number of audit findings because of its capability to describe important elements of audit quality such as competence and independence. The auditor's ability to find material weaknesses reflects the level of his/her competence. An auditor who managed to find material weaknesses during the audit process has to report it to the stakeholders. Auditor has to free himself/herself from the pressure of any party. Audit Report on the public sector is a means for auditors to convey information about material weaknesses to stakeholders. The main objective of this study is to investigate the comparison of audit findings in local government's financial audit reports in Indonesia, by BPK and PAF auditors. This study also aims to investigate the differences between the number of audit findings reported by BPK auditors and PAF auditors at every fiscal period from 2016 until 2018. The study hopefully will confirm that using PAF auditors will not produce any different results in audit quality. Thus, BPK can continue to use the services of PAF for future audits.
The study uses a number of audit findings that were reported in financial audit reports. These audit findings have passed tiered reviews. There were audit findings that were not reported. This review process eliminated many audit field findings so that the reported audit findings were all selected quality findings. Therefore, the study only uses the reported audit findings because they will explain more aspects of all steps and the overall quality of the audit process.

BPK should have audited a total of 533 local government financial reports in 2016. The Summary of Semi-Annually Audit Reports (IHPS) 1 in 2016 stated that 12.166 findings or an average of 22,826 findings were found in 2016. The average of these findings was much greater than the average of the findings produced by the PAF in 2016, which amounted to 10,920 findings. This showed a glimpse of the difference between PAF and BPK auditors. However, the number of local government financial reports that were audited by PAF auditors was much smaller than the overall number of local government financial reports audited by BPK in 2016. PAF auditors provided a downward trend of the number of findings in 2017 , but they increased their number of findings in 2018. The average audit findings produced by PAF auditors in 2017 was 10,667, which decreased by $2.32 \%$ compared to their average findings of 10,920 in 2016. However, an increase of $30.44 \%$ in the average number of findings occurred in 2018 compared to the average number of findings in 2017. The increase in the number of findings in 2018 indicated that PAF auditors increased their competence and experience in conducting government financial audit. The next sections will explain the literature review, methodology, results, analysis of results, and conclusions.

\section{LITERATURE REVIEW AND HYPOTHESIS DEVELOPMENT}

\subsection{Agency Theory and Audit Quality}

Agency theory cannot be separated from the relationship between the principal and the agent. Streim (1994) applied agency theory on government institutions to see the relationship between the principal and the agent relationship in that context. The principal and agent relationship in the public sector includes three main types of relationship (Streim, 1994). First, the relationship between voters/people with legislators. McCormick and Tollison (1981) stated that the democratic system enables voters and taxpayers to be owners or principal, while the legislative members elected in a general election are agents. Indonesia is a country that adheres to the democratic system. People or taxpayers have the right to choose their representatives in the legislature/parliament for a five-year mandate. The legislative members have the authority to represent 
the people or taxpayers by determining the management policies of the government. Second, the relationship between the legislature and the government. The third and last relationship type in the public sector is the relationship between ministers and their bureaucrats.

The study focuses on the second principal and agent relationship proposed by Strein (1994), the relationship between the legislature and the government. The dependence of the government budget to the legislative members indicate the relationship between the two (Streim, 1994). The government is the organization led by the president or the prime minister and consists of the ministers, in a system that is often referred to as the bureaucracy. In Indonesia, the government consists of the central and local governments. The central government is led by the president, while the local governments are headed by the Regional Headers or Municipals. The government's task is to manage government activities that are financed by a budget. Government budgeting is the result of discussions between the government and the parliament. The new budget can be executed after the approval of the parliament. The government is also obliged to account for the implementation of the budget to parliament. This condition indicates dependence and the agency relationship between the government and parliament. In this agency relationship, the relationship between the government and the bureaucracy. The government consists of the president as the leader and the ministers appointed to lead their respective ministries. While the bureaucracy refers to a high-ranking official in a ministry. The relationship between ministers and bureaucratic leaders often causes a conflict of interest (Streim, 1994). Bureaucratic leaders tend to lead the organization to maximize its interests in a certain bureaucracy. Bureaucratic leadership has the advantage of internal information on the organization. This is the third agency relationship in the context of the public sector between ministers as principal and chairman of the bureaucracy as an agent (Streim, 1994).

The second type of Strein's theory is the relationship between legislative members as principal and president and his/her ministers or municipals as an agent. The government proposes a budget to legislative members for approval. The government runs its activities according to the budget and reports it to legislative members at the end of the fiscal period. Agency problem appears when the government has more information about its activities than the members of the legislative. Moreover, ministers who are appointed by the president have their own interest in using the budget. Legislative members as principal have to ensure that government complies with the budget and the assurance service from auditors is a necessity. Legislative members choose their auditors to conduct financial reports audit to minimize agency problems. Better quality of auditors will result in the better quality of audit. The inclusion of PAF auditors in government financial audit aims to trigger competition with government auditors, to improve audit quality. The better audit quality will decrease the probability of problems.

\subsection{Hypotheses Development}

The probability of finding weaknesses in the client's accounting system depends on the technical competence of auditors. While the possibility of reporting these weaknesses depends on the degree of freedom of the auditors from all pressures that may affect their independence. Several studies in the private sector assumed that the competence of auditors was at the fixed level since independence is crucial for auditors (DeAngelo, 1981, Goldman \& Barlev, 1974, Nichols \& Price, 1976). The process of finding accounting client system weaknesses is difficult to be investigated because of the limited availability of data from auditors' working papers. Nonetheless, independence is observed in the audit reports that can be easily accessed by researchers.

The main characteristic of audit in the private sector is a strong competition between auditors, despite large PAF auditors, often became dominant (Doogar \& Easley, 1998, Knapp, 1990). Clark et al. (2007) state that the public sector audit tend to be monopolized behavior by the SAI. The provision of audit services to government organizations and other public sector organizations are dominated by the SAI in a particular jurisdiction. Clark et al. (2007) state that the absence of competition could eliminate the incentive for enhancing audit quality in the public and private sectors. Some areas of jurisdictions are trying to generate competition by giving opportunities for PAF auditors to compete with SAI auditors. Indonesia is one of the countries that started to give opportunity to the PAF auditor to audit government agencies since 2012.

Clark et al. (2007) state that the competence and independence of auditors are also important for audit quality in both the private and the public sectors. Both of these principles demonstrate the quality of the audit. Implementation of quality audits in the public sector will increase the accountability of the government's financial reports. Deis and Giroux (1992) stated that the quality of governance is the extent of auditors' compliance with government auditing standards. Copley and Doucet (1993) stated that quality audit mechanisms were established by supply and demand in a market audit.

DeAngelo (1981) defines audit quality as the probability of an auditor to detect and report weaknesses in a client's accounting system. The material misstatements occurred when the client's internal control system has many weaknesses (Eilifsen \& 
Messier, 2000). Thus, the more successful the auditor is in discovering and reporting the weaknesses in the client' system, the higher the audit quality will be. The success of the auditors in finding weaknesses demonstrates the competence and independence of the auditors

Public sector audit provides opportunities for researchers to be able to assess audit quality by using audit findings (Cagle \& Pridgen, 2015). Audit findings are all the material weaknesses that have been found by auditors during the performance of the government financial audit. This study uses the number of audit findings as a measurement of the audit quality since it demonstrates the two important elements of audit quality, competence and independence. Auditors who find material weaknesses must communicate to stakeholders. Auditors must free from the pressure of any party; so, information about the finding weaknesses can be delivered to stakeholders. Audit Report on the public sector is a means for auditors to convey information about material weaknesses to stakeholders. Audit findings contained in the audit report can describe the freedom and independence of the auditor.

Regarding the financial statement audits of the government in Indonesia, SPKN (2007) states that the auditor is obliged to find weaknesses in the system of internal control and noncompliance with laws and regulations. Auditors are also obliged to report any weaknesses in the system of internal control and noncompliance with laws and regulations in the form Inspection Report (LHP). Auditors with competence in performing financial statement audits of government in Indonesia have a greater probability of finding the weakness of internal control systems and noncompliance with laws and regulations.

A comparison of audit quality between BPK auditors and PAF auditors can be explained through incentives and motivation of both to carry out a quality audit. Cagle and Pridgen (2015) state that auditors who have greater pressure to maintain their reputation tend to keep up with the good quality of their audit. PAF auditors have a greater reputation pressure than BPK auditors. PAF auditors must be certified to be able to conduct audit of the government financial reports in Indonesia. The certification aims to enhance the implementation of quality audit; therefore, PAF auditors should always maintain their performance and competence in order to retain their certification. Besides, PAF auditors have to participate in an auction mechanism and compete with other PAF auditors. Two of the requirements of the auction process is the qualification of PAF auditors and their experiences in performing public sector audit. PAF auditors will be more encouraged to produce better audit quality because they need to maintain their reputation. These incentives will make PAF auditors easier to compete with other auditors. BPK auditors operate in a monopolistic environment where they do not have to compete in the auction to get clients. BPK auditors are conducting the audit because it mandated by the legislation; therefore, they do not need experience to maintain their reputation. Based on the above arguments, the hypothesis of this study is the following

H1: PAF auditors will produce more audit findings than BPK auditors when performing audits of government financial reports in Indonesia.

\section{RESEARCH METHOD}

\subsection{Data and Sample}

The study uses data from Local Government Financial Reports for the fiscal year of 2015 to 2017. Audit Reports of local government financial audit from 2016 to 2018 were collected. The follow-up result reports of 2016 until 2018 and other documents required to support the research were gathered from BPK RI Semiannually Reports. All documents and data that were used in this study were collected from BPK RI.

This study uses two groups of samples. The first sample group consisted of local governments that were audited by PAF auditors, paired with other local governments that were audited by BPK auditors using a paired match criterion. We selected local governments that will be paired in this study by using the following criteria. First, the pairing local government samples should be in the same province as the local governments, which were audited by PAF auditors. Second, the paired local government samples should have the same audit opinion as the previous year's financial reports to ensure the same level of audit risk. Third, the paired local government samples should not have any significant difference in total expenditures to reveal the process of a large audit coverage. Additionally, the Technical Guidelines of government financial report audit of materiality in 2013 stated that the determination of the nominal value of materiality in the financial audit is using the total expenditures. Fourth, There is no significant difference of the percentage of accumulated follow-up completion (TLHP) between local government and its paired sample for for the period ends in December 31 of the year before the financial audit were conducted. The second group of samples audited by PAF auditors consist of local governments paired with the same local governments that were audited by BPK auditors in the previous year. The use of two different groups of paired match samples will ensure that the result of this study is reliable. 


\subsection{Research Model}

The study uses a model that was adopted from Cagle and Pridgen (2015) and Lopez and Peters (2010) studies as presented as follows.

$$
\begin{aligned}
\text { FINDINGS }_{\mathrm{i}}= & \beta_{0}+\beta_{1} \text { AUDITORTYPE }_{\mathrm{i}}+\beta_{2} \operatorname{lnSIZE}_{\mathrm{i}}+ \\
& \beta_{3} \operatorname{lnGOVEXP}_{\mathrm{i}}+\beta_{4} \text { COMPLEX }_{\mathrm{i}}+\beta_{5} \\
& \text { TIME }_{\mathrm{i}}+\beta_{6} \text { AGE }_{\mathrm{i}}+\beta_{7} \text { TOTTLHP }_{\mathrm{i}}+\varepsilon(1)
\end{aligned}
$$

Table I. Summary of Variable Operationalization

\begin{tabular}{|l|l|l|}
\hline Variables & Measurement & Expectation \\
\hline FINDINGS & $\begin{array}{l}\text { Dependent variables, } \\
\text { number of audit } \\
\text { findings }\end{array}$ & N/A \\
\hline $\begin{array}{l}\text { AUDITOR } \\
\text { TYPE }\end{array}$ & $\begin{array}{l}\text { Dummy variables, 1 } \\
\text { is PAF auditors, 0 is } \\
\text { BPK auditors }\end{array}$ & Positive \\
\hline LnSIZE & $\begin{array}{l}\text { The natural logarithm } \\
\text { of total assets }\end{array}$ & Positive \\
\hline lnGOVEXP & $\begin{array}{l}\text { Natural logarithm } \\
\text { expenditure }\end{array}$ & Positive \\
\hline COMPLEX & $\begin{array}{l}\text { Number of SKPD / } \\
\text { OPD }\end{array}$ & Positive \\
\hline TIME & $\begin{array}{l}\text { Duration of the audit } \\
\text { AGE }\end{array}$ & Positive \\
\hline TOTTLHP administrative & $\begin{array}{l}\text { Negative } \\
\text { percentage of } \\
\text { completion as of } \\
\text { December 31 the } \\
\text { previous year }\end{array}$ & Negative \\
\hline
\end{tabular}

The dependent variable of the study is the number of audit findings resulted by BPK auditors and PAF auditors. The study assume that the level of audit quality should be showed by how many audit findings reported by auditors. The main independent variable is AUDITOR TYPE. It is a dummy variable consist of 1 for PAF auditors and 0 for BPK auditors. Based on the hypothesis argument, PAF auditors will report more audit findings compared with BPK auditors.

Control variables used in the study are LnSIZE, lnGOVEXP, COMPLEX, TIME, AGE, and TOTTLHP. LnSIZE represent the size of local government which is calculated by the amount of total assets. The bigger the local government the more probability that auditor would find audit findings. Government expemditure have similar characteristic with the amount of total assets. COMPLEX represent the complexity that auditors will be faced for their audits. The higher the complexity the more auditor need to higher their assurance so that the probability to find defficiencies should be higher. Variable TIME measures how long the audit field will be conducted and more time will give more chance for auditor to find defficiencies. AGE measure the age of local governments. They should be more matured every year. The matured local governments have more strenght of control so that auditor will increase their believe for control effectiveness of local governments. Variable TOTTLHP measures the accumulated percentage of audit recommendation completion as of December 31 the previous year. The completion of audit recommendations should guarantee that the previous audit findings will not be happened again in the future.

\section{RESULT AND DISCUSSION}

\subsection{Statistic Descriptive}

The descriptive statistics of the first and second

\begin{tabular}{|c|c|c|c|c|c|c|}
\hline $\begin{array}{l}\text { Varia- } \\
\text { bles }\end{array}$ & Group & $\mathbf{N}$ & Min & Mean & $\begin{array}{l}\text { Std. } \\
\text { Dev. }\end{array}$ & Max \\
\hline \multirow{4}{*}{$\begin{array}{l}\text { Size } \\
\text { (Trillion } \\
\text { IRD) }\end{array}$} & PAF & 72 & 0.85 & 2.740 & 1.530 & 7.81 \\
\hline & & & 0 & & & 0 \\
\hline & BPK & 72 & 0.65 & 2.710 & 1.630 & 7.91 \\
\hline & & & 0 & & & 0 \\
\hline \multirow{3}{*}{$\begin{array}{l}\text { GovExp } \\
\text { (Trillion } \\
\text { IRD) }\end{array}$} & PAF & 72 & 0.46 & 1,290 & 0.655 & 3,10 \\
\hline & & & 3 & & & 0 \\
\hline & BPK & 72 & $\begin{array}{r}0.45 \\
0\end{array}$ & 1,310 & 0.615 & $\begin{array}{r}3,14 \\
0\end{array}$ \\
\hline \multirow{3}{*}{$\begin{array}{l}\text { Comple } \\
\text { X }\end{array}$} & PAF & 72 & 28 & 44.68 & 11.80 & 74 \\
\hline & & & & 1 & 8 & \\
\hline & BPK & 72 & 27 & 48.75 & $\begin{array}{r}12.10 \\
7\end{array}$ & 76 \\
\hline \multirow[t]{2}{*}{ Time } & PAF & 72 & 30 & $\begin{array}{r}49.08 \\
3\end{array}$ & $\begin{array}{r}15.68 \\
8\end{array}$ & 83 \\
\hline & BPK & 72 & 26 & $\begin{array}{r}45.66 \\
7\end{array}$ & $\begin{array}{r}17.35 \\
4\end{array}$ & 83 \\
\hline \multirow[t]{4}{*}{ Age } & PAF & 72 & 7 & $\begin{array}{r}42.48 \\
6\end{array}$ & $\begin{array}{r}23.64 \\
5\end{array}$ & 67 \\
\hline & BPK & 72 & 3 & $\begin{array}{r}47.01 \\
4\end{array}$ & $\begin{array}{r}23.10 \\
2\end{array}$ & 69 \\
\hline & BPK & 72 & 0.63 & 0.864 & 0,072 & 0.97 \\
\hline & BPK & 72 & 3 & 3.889 & 0,316 & 4 \\
\hline \multirow{3}{*}{$\begin{array}{l}\text { Tot- } \\
\text { TLHP }\end{array}$} & PAF & 72 & 0.48 & 0.850 & 0.122 & 0.99 \\
\hline & & & 5 & & & 4 \\
\hline & BPK & 72 & $\begin{array}{r}0.61 \\
7\end{array}$ & 0.828 & 0.103 & $\begin{array}{r}1,00 \\
0\end{array}$ \\
\hline
\end{tabular}
subsample are presented in Table II and III.

Table II. Descriptive Statistics of SubSamples 1

Table III. Descriptive Statistics of Sub Samples 2

\begin{tabular}{|l|l|l|r|r|r|r|}
\hline $\begin{array}{l}\text { Varia- } \\
\text { bles }\end{array}$ & $\begin{array}{l}\text { Grou } \\
\text { p }\end{array}$ & $\mathbf{n}$ & Min & mean & $\begin{array}{l}\text { Std. } \\
\text { Dev. }\end{array}$ & Max \\
\hline $\begin{array}{l}\text { Size } \\
\text { (Trillion }\end{array}$ & PAF & 66 & 0.85 & 2,660 & 1,43 & 7.31 \\
IRD) & BPK & 66 & 0,54 & 2,670 & 1,52 & 8,20 \\
\cline { 2 - 7 } & & & 8 & & 0 & 0 \\
\hline $\begin{array}{l}\text { GovExp } \\
\text { (Trillion }\end{array}$ & PAF & 66 & 0.46 & 1,290 & .663 & 3,10 \\
IRD) & BPK & 66 & 0.41 & 1,220 & .598 & 2,50 \\
\hline
\end{tabular}




\begin{tabular}{|l|l|l|r|r|r|r|}
\hline & & & 7 & & & 0 \\
\hline $\begin{array}{l}\text { Com- } \\
\text { plex }\end{array}$ & PAF & 66 & 28 & 44.04 & 11.0 & 74 \\
& & & & 5 & 61 & \\
\cline { 2 - 7 } & BPK & 66 & 26 & 44.87 & 11.0 & 74 \\
& & & & 9 & 01 & \\
\hline Time & PAF & 66 & 30 & 49.86 & 15.8 & 83 \\
& & & & 3 & 42 & \\
\cline { 2 - 7 } & BPK & 66 & 26 & 44.65 & 15.9 & 78 \\
\hline Age & PAF & 66 & 7 & 42.31 & 23.7 & 67 \\
& & & & 8 & 82 & \\
\cline { 2 - 7 } & BPK & 66 & 6 & 41.18 & 23.8 & 66 \\
& & & & 2 & 74 & \\
\cline { 2 - 7 } & BPK & 66 & 4 & 4 & 0 & 4 \\
\hline \multirow{2}{*}{$\begin{array}{l}\text { Tot- } \\
\text { TLHP }\end{array}$} & PAF & 66 & 0,47 & .851 & 0,12 & 0.99 \\
& & & 8 & & 5 & 4 \\
\cline { 2 - 7 } & BPK & 66 & 0.48 & .863 & 0.11 & 1,00 \\
& & & 5 & & 9 & 0 \\
\hline
\end{tabular}

\begin{tabular}{|c|c|c|c|c|c|c|c|}
\hline & & & & $*$ & & & \\
\hline $\begin{array}{l}\text { Com- } \\
\text { plex }\end{array}$ & + & 0,039 & $\begin{array}{r}0.13 \\
3\end{array}$ & & $\begin{array}{r}0,04 \\
9\end{array}$ & $\begin{array}{r}0.09 \\
3\end{array}$ & \\
\hline Time & + & 0,044 & $\begin{array}{r}0,02 \\
4\end{array}$ & * & $\begin{array}{r}0,02 \\
7\end{array}$ & .101 & \\
\hline Age & - & 0,020 & $\begin{array}{r}0.17 \\
7\end{array}$ & & $\begin{array}{r}0,02 \\
9\end{array}$ & $\begin{array}{r}0.08 \\
9\end{array}$ & \\
\hline $\begin{array}{l}\text { TotTLH } \\
\text { P }\end{array}$ & - & $\begin{array}{r}-8.78 \\
9\end{array}$ & $\begin{array}{r}0,00 \\
5\end{array}$ & $\begin{array}{l}* \\
* \\
*\end{array}$ & $\begin{array}{r}-9.5 \\
83\end{array}$ & $\begin{array}{r}0,00 \\
1\end{array}$ & \\
\hline $\begin{array}{l}\text { Constant } \\
\text { s }\end{array}$ & & $\begin{array}{r}19.68 \\
9\end{array}$ & $\begin{array}{r}0.26 \\
2\end{array}$ & & $\begin{array}{r}53.4 \\
56\end{array}$ & $\begin{array}{r}0,03 \\
3\end{array}$ & \\
\hline \multicolumn{2}{|l|}{$\mathrm{N}$} & \multicolumn{3}{|l|}{144} & \multicolumn{2}{|l|}{132} & \\
\hline \multicolumn{2}{|l|}{ Prob> F } & \multicolumn{3}{|l|}{.0087} & \multicolumn{2}{|l|}{.0067} & \\
\hline \multicolumn{2}{|l|}{ R-squared } & \multicolumn{2}{|l|}{$12.71 \%$} & & \multicolumn{2}{|l|}{$14.29 \%$} & \\
\hline
\end{tabular}

Characteristics of the data in variables such as lnSIZE, lnGOVEXP, COMPLEX, AGE, and TotTLHP between PAF auditors and BPK auditors are similar. The paired criterion ensures the similarity between them. The criterion used to obtain samples aim to make the same audit risk level between PAF and BPK auditors. We hope that the audit results that are generated by the two types of auditors can be compared fairly in determining the level of audit quality.

\subsection{Regression Result}

The regression result showed in Table IV explains the effect of auditor type to audit findings is not significance. The regression results of both for subsample 1 and subsample 2 show that the use of PAF auditors has no significant impact on the number of audit findings. The value of Prob $>|\mathrm{t}|$ for subsample 1 is 0.123 and for subsample 2 is 0.210 . The coefficient of AUDITORTYPE variable is negative for both subsamples. Although the use of PAF auditors does not affect the number of findings, they produced fewer audit findings compared to BPK auditors. These results do not support the hypothesis study that stated that the use of PAF auditors could produce a larger amount of audit findings compared to BPK auditors.

Table IV. Results Regression on Two subsamples

\begin{tabular}{|l|l|r|r|r|r|l|l|}
\hline $\begin{array}{l}\text { Varia- } \\
\text { bles }\end{array}$ & $\begin{array}{l}\text { Ex } \\
\text {. }\end{array}$ & \multicolumn{2}{|l|}{ subsample 1 } & \multicolumn{3}{l|}{ subsample 2 } \\
\hline $\begin{array}{l}\text { Dep. : } \\
\text { FINDINGS }\end{array}$ & Koef. & $\begin{array}{l}\text { Pro } \\
\text { b. }\end{array}$ & & \multicolumn{2}{l|}{$\begin{array}{l}\text { Koef } \\
\text {. }\end{array}$} & $\begin{array}{l}\text { Pro } \\
\text { b. }\end{array}$ & \\
\hline $\begin{array}{l}\text { Auditor- } \\
\text { Type }\end{array}$ & + & -0.85 & 0.12 & & -0.5 & .210 & \\
\hline $\operatorname{lnSize}$ & + & 3.536 & 0,00 & $*$ & 2.68 & 0,01 & $*$ \\
& & & 15 & $*$ & 9 & 3 & $*$ \\
& & & & $*$ & & & \\
\hline lnGov- & + & -3.76 & 0.00 & $*$ & -4.0 & 0,00 & $*$ \\
Exp & & 7 & 18 & $*$ & 73 & 6 & $*$ \\
\hline
\end{tabular}

The results of this study are different from the results of Cagle and Pridgen (2015), Jakubowski (2008), Jeffrey (2011) and parts of the results of López and Peters (2010). Jeffrey (2011) suggested that government auditors reported more findings compared with PAF auditors. López and Peters (2010) maintained a positive impact of auditor type on the number of audit findings. However, a significant impact only resulted from large PAF auditors. The results of this study confirm López and Peters (2010) results that the use of a small PAF does not have a significant impact on the number of audit findings. A PAF that conducted an audit on behalf of BPK since 2016 was categorized as small a PAF. Many big PAF in Indonesia has not been keen to compete in the market of government auditing.

Fauziah, et.al. (2017) maintain that the use of PAF auditors produced less number of findings than BPK auditors. This study was conducted on a sample of 25 local government financial reports and 9 ministry financial reports in 2016 audited by PAF auditors. Fauziah et.al. (2017) argued that PAF auditors had less experience in government auditing than BPK auditors. Experience is a factor that can make a difference in the audit results. We support the result of Fauziah, et.al. (2017) by maintaining that the number of audit findings produced by PAF auditors are fewer than BPK auditors. However, this study also maintains that there is no significant impact on the type of auditor to the number of audit findings.

Table V. The number of different test findings per year

\begin{tabular}{|l|l|l|l|l|r|r|}
\hline $\begin{array}{l}\text { The } \\
\text { sample } \\
\text { group }\end{array}$ & Year & $\mathbf{n}$ & \multicolumn{2}{|l|}{ mean } & diff. & $\begin{array}{l}\text { Sig- } \\
\text { nifi- } \\
\text { cance }\end{array}$ \\
\cline { 4 - 7 } $\begin{array}{l}\text { Sub- } \\
\text { sample }\end{array}$ & 2016 & 25 & 10.920 & 14,000 & -3080 & $\begin{array}{r}0.0189 \\
* *\end{array}$ \\
\cline { 2 - 7 } 1 & 2017 & 12 & 10.667 & 12.833 & -2.167 & .1769 \\
\cline { 2 - 7 } & 2018 & 35 & 13.914 & 12.886 & 1.029 & .3297 \\
\hline \multirow{2}{*}{$\begin{array}{l}\text { Sub- } \\
\text { sample } \\
2\end{array}$} & 2016 & 25 & 10.920 & 12.320 & -1.400 & .2288 \\
\cline { 2 - 7 } & 2017 & 7 & 12.571 & 13.857 & -1.286 & .6405 \\
\cline { 2 - 7 } & 2018 & 34 & 14.147 & 13,765 & 0.382 & .6898 \\
\hline
\end{tabular}


Table V shows that PAF auditors' average number of findings are always increasing every year. The mean difference of audit findings between PAF and BPK auditors is $-3,08$ for subsample 1 and $-1,40$ for subsample 2 in the first year when PAF auditors started to conduct local government financial audit. Moreover, that difference is significant for subsample 1 . The mean difference of audit findings between PAF and BPK auditors decreased in 2017 compared to 2016 both for subsample 1 and subsample 2 . This result shows that the increasing experience of PAF auditors in conducting local government financial audit has made greater number of their audit findings.

Furthermore, the mean difference of audit findings between PAF and BPK auditors in 2018 was 1,029 for subsample 1 and 0,382 for subsample 2. This result indicates that PAF auditors reported greater number of audit findings compared with BPK auditors. In 2018, PAF auditors conducted 35 local government financial audit and 16 of them were audited by PAF auditors with at least two years of experience. Moreover, 3 of the total 35 local government financial reports were audited by PAF auditors with one year experience. Those results show that PAF auditors' experiences in conducting local government financial audits have resulted in a greater number of audit findings and have decreased the differences in audit quality compared with BPK auditors. Although the hypothesis is rejected, we suggest that the more experienced PAF auditors will result in more audit quality.

\section{CONCLUSION AND IMPLICATION}

This study aims to investigate the quality of local government audit between PAF and BPK auditors. The results show that the type of auditor does not affect audit quality as measured by the number of audit findings. The law mandates BPK to conduct government financial audit every year. The local government financial audit was held simultaneously every year; thus, BPK has to mobilize all the resources they have. BPK requires the services of PAF to help them fulfill the mandate. However, BPK also has to maintain their desired level of audit quality. This study explains the effect of using PAF auditors to local government audit quality for three years from 2016 to 2018. Previous studies such as Fauziah, et. al. (2018) suggested that the use of PAF auditors had negative effect on the number of audit findings. This study maintains that the use of PAF auditors has no significant effect on the number of audit findings. This result suggests that PAF auditors' experience in conducting local government financial audit is an important factor which has been eliminated those significant negative effect. Therefore, BPK has to continue involving PAF in the government financial audit process.
This study has several limitations. This study doesn't separate audit findings as internal control weaknesses and compliance findings. Samples in this study are relatively small compared with the population. Local government financial reports that were audited by PAF auditors from 2016 to 2018 were very few compared with total local government financial reports that were mandated to be audited by BPK. Further researchers might be interested to expand the result of this study for example by investigating audit efficiency of using PAF auditors in conducting government financial audit.

\section{REFERENCES}

[1] Alkins, S.K. (2012). 'Determinants of the auditee adoption of audit recommendations: Local government auditors' perspectives. Journal of Public Budgeting', Accounting, and Financial Management, 24 (2), 195-220.

[2] Asian Organization of Supreme Audit Institutions, (2009). Quality Assurance in Financial Audit Handbook. ASOSAI

[3] Cagle, C.S., \& Pridgen, A.B. (2015). 'Accountability in county governments: Is the auditor type related to audit quality?' Journal of Leadership, Accountability, and Ethics, 12 (1), 7994.

[4] Chong, K.M., Dolley, C., Houghton, K., \& Monroe, G.S. (2009). 'Effect of outsourcing of public sector audits on cost-efficiency'. Accounting and Finance, 49 (4), 675-695. https://doi.org/10.1111/j.1467-629X.2009.00302.x

[5] Chu, L., Simunic, DA, Ye, M., \& Zhang, P. (2018). 'Transaction costs and competition among audit firms in local markets'. Journal of Accounting and Economics, 65, 129-147.

[6] Ciconte, W., Knechel, W.R, \& Schelleman, C. (2015). An examination of the relation between market structure and the profitability of audit engagements. Accounting and Finance, 55 (3), 749-781. https://doi.org/10.1111/acfi.12078

[7] Clark, C., De Martinis, M., \& Krambia P.A. (2007). 'Audit quality attributes of supreme audit institutions of the European Union'. European Business Review, 19, 40-71. https://doi.org/10.1108/09555340710714144

[8] Copley, PA, \& Doucet, M.S. (1993). The Impact of Competition on the Quality of Governmental Audits. Auditing: A Journal of Practice and Theory, 12 (1), 88-98.

[9] DeAngelo, L.E. (1981). 'Auditor size and audit quality'. Journal of Accounting and Economics, 3 
(3), 183-199. https://doi.org/10.1016/01654101(81)90002-1

[10] Giroux, G., \& Jones, R. (2011). 'Measuring audit quality of local Governments in England and Wales'. Research in Accounting Regulation, 23 (1), 60-66. https://doi.org/10.1016/j.racreg.2011.03.002

[11] Jeffrey, L. (2011). 'To find or not to find: public versus governmental accounting auditors auditors'. Review of Business Information Systems, 15 (4), 510.

[12] Knechel, RW, Rouse, P., \& Schelleman, C. (2009). 'A modified production audit framework: Evaluating the relative efficiency of audit engagements'. Accounting Review, 84 (5), 1607 1638. https://doi.org/10.2308/accr.2009.84.5.1607

[13] Liu, J., \& Lin, B. (2012). 'Government auditing and corruption control: Evidence from China's provincial panel data'. Chinese Journal of Accounting Research, 5 (2), 163-186. https://doi.org/10.1016/j.cjar.2012.01.002

[14] López, D.M., \& Peters, G.F. (2010). 'Internal control reporting public and governmental differences among auditors: The case of city and county Circular A-133 audits'. Journal of Accounting and Public Policy, 29 (5), 481-502. https://doi.org/10.1016/j.jaccpubpol.2010.06.003

[15] O'Keefe, TB, Simunic, D. A, \& Stein, M.T. (1994). 'The production of audit services: evidence from a major public accounting firm'. Journal of Accounting Research, 32 (2), 241-261. https://doi.org/10.2307/2491284

[16] Overview 1st Semester Examination Results 2016, the Audit Board of the Republic of Indonesia.
[17] Regulation of the Audit Board of Indonesia No. 1 of 2007 on State Financial Inspection Standards.

[18] Samelson, D., Lowensolm, S., \& Johnson, L.E. (2006). 'The determinants of perceived quality and auditee satisfaction audit in local government'. Journal of Public Budgeting, Accounting, and Financial Management, 18 (2), 139-166. https://doi.org/10.1108/MBE-09-2016-0047

[19] Semester Examination Results Summary 1 In 2015, the Audit Board of the Republic of Indonesia.

[20] Semester Examination Results Summary 1 In 2017, the Audit Board of the Republic of Indonesia.

[21] Semester Examination Results Summary 1 In 2018 , the Audit Board of the Republic of Indonesia.

[22] Setyaningrum, D., Gani, L., Martani, D., \& Kuntadi, C. (2013). 'The effect of auditor quality on the follow-up of the audit recommendation'. International Research Journal of Business Studies, 6 (2), 89-104.

[23] Setyaningrum, Dyah (2013), Quality Auditor, the Legislative Oversight and Accountability Utilization Audit In Financial Management, Dissertation, University of Indonesia.

[24] TubbsRichard M, (1992) 'The effect of experience on the auditor organization and amount of knowledge'. The Accounting Review, 783-801

[25] Wicaksono, Panggah Tri (2012) Analysis of Factors Affecting Audit Opinion and Findings on the Finance Report of the Regional Government of Regency / City in Indonesia Year 2008-2009. Thesis: University of Indonesia. Depok, Unpublished 